\title{
Vlachs and Slavs in the Middle Ages and Modern Era
}

Wołosi i Słowianie w średniowieczu i w epoce nowożytnej

\section{STRESZCZENIE}

Analiza relacji wołosko-słowiańskich w średniowieczu pozwoliła ustalić pewne prawidłowości w procesie slawizacji Wołochów/Włachów lub też odwrotnie - w jego braku. Za najważniejsze skutki kontaktów wołosko-słowiańskich w średniowieczu i wczesnej epoce nowożytnej uznano:

1. Slawizację znacznej części Wołochów/Włachów i ich ewolucję w kierunku narodowości bułgarskiej, serbskiej, czarnogórskiej, chorwackiej, bośniackiej, ruskiej, słowackiej, polskiej.

2. Silną obecność kultury i tradycji słowiańskiej w średniowiecznych państwach rumuńskich - księstwach Wołoszczyzny i Mołdawii.

3. Pogłębienie mozaiki etnicznej Bałkanów i obecność etnicznych Wołochów/Włachów także na terenach nizinnych.

4. Wzajemne przenikanie się kultur i tradycji: schodzenie Wołochów/Włachów na niziny i podejmowanie działalności rolniczej oraz stopniowe oswajanie gór przez Słowian.

Słowa kluczowe: Wołosi/Własi, Słowianie, procesy slawizacyjne, przenikanie się kultur i tradycji

As the main distinguishing features of historical Vlach ethnos should be considered the following features:

1. Language on Romance basis.

2. The practice of pastoralism (mainly mountain one).

3. Cohabitation with other ethnic groups: Greeks, Albanians, Cumans, Hungarians, and most of all Slavs.

The latter factor played a major role in the evolution of particular groups of Vlachs. 
On the one hand, the relations between the Vlachs and Slavs were the result of the expansion of the Southern Slavs in the Balkans and, on the other hand, they resulted from the expansion of Vlachs in a northerly direction, to the northern slopes of the Carpathians, and further, to the lowland areas of southern Poland and Ukraine of today.

Assuming that the Vlach population was already established in the Balkans during the migration of Slavs, it should be pointed out that both ethnic groups occupying the same land were not in conflict. Slavs, as farmers, occupied lands in the valleys, which were suitable for them, while Vlachs exploited mountains. Slavs, next to agriculture, also engaged in breeding, but did not practice transhumance pastoralism, which was the domain of the Vlachs.

For the Slavs the land and the right to its cultivation and ownership was most important, for the Vlachs the ownership of land did not matter as long as the mountains were common property. The element, which bound their community together, was not the land, but family relationships, the sense of belonging to the clan and the specific corporation of the katun.

The development of state structures, ownership and social relations brought the evolution of relationships, which proceeded differently in different areas.

Among the countries that we can define as Slavic, the earliest historical sources mention the presence of Vlachs in Bulgaria. According to the testimony of Byzantine writer Georgios Kedrenos, David, the brother of the Bulgarian Tsar Samuel, reigning in the late $10^{\text {th }}$ and $11^{\text {th }}$ century, was killed by "wandering Vlachs" travelling between Kastoria and Prespa ${ }^{1}$. Byzantine princess Anna Commena, who writes in the $12^{\text {th }}$ century, mentions numerous Vlachs, nomads living in Bulgaria ${ }^{2}$. It should be noted that Anna Comnena wrote it at a time when the Bulgarian state did not exist for over a hundred years. Thus, it is necessary to ask, which territory in her chronicle could be called Bulgaria? It could only be Byzantine themata of Bulgaria, which was located in the western part of Macedonia.

The presence of numerous Vlachs in this area is confirmed during the construction of the second Bulgarian state after the great anti-Byzantine

${ }^{1}$ Georgius Cedrenus, Joannus Skylitzes opere, II, Bonnae 1839, p. 435.

${ }^{2}$ Anna Komnena, Aleksjada, transl. O. Jurewicz, vol. 1, Wrocław-Warszawa-Kraków 1967, p. 131; vol. 2, Wrocław-Warszawa-Kraków 1972, books 8,3, p. 34, books 10,3, pp. 73-74.

Anna Comnena, The Alexiad, transl. E. A. S. Dawes, Cambridge, Ontario 2000, “Ezeba, this is a Vlach village situated close to Androneia" book 5,5, p. 90; book 8,3, p. 141; book 10,3, pp. 170-171. 
uprising of 1185 . The creators of the restored state, Asen dynasty, appealed to the traditions of the Bulgarian state, but they were of Cuman-Vlach origin and adopted the title of tsar of Bulgarians, Vlachs and Cumans.

In 1203-1204 the Bulgarian tsar Kaloyan wrote in letters to Pope Innocent III that he reigns over Bulgarians and Vlachs like his ancestors, tsars Simeon, Peter and Samuel - the first rulers of the Bulgarian state in the $10^{\text {th }}-11^{\text {th }}$ century ${ }^{3}$. More than that, in the correspondence between the Pope and Kaloyan of Bulgaria for the first time appeared the term "Blachia" in the territorial meaning.

Bulgarian tsar sent to the Pope the Archbishop of Bulgaria and Vlachia, Basil, while Innocent III in his edict of 25 February 1204 gave royal crown to Kaloyan and established the Roman Catholic Church for the province of Bulgaria and Blachia/Vlachia. It can be concluded that the Bulgarian state entered the territory so densely populated by Vlachs that it could have been named Vlachia, and that it had to have some specific administrative framework as it was considered a province ${ }^{4}$.

Additionally, chroniclers of the fourth crusade, Geoffroy de Villardhuin and Robert de Clari, referred to the Bulgarian tsar as John of Vlachia $(\text { Blakia) })^{5}$. One might ask where this Vlahia province was situated. Robert de Clari wrote that it was a province belonging to the Byzantine emperor, who rebelled against him. It was harsh and inaccessible land, which could have been accessed only by ravines. Undoubtedly, we cannot identify this Vlachia with the Wallachian Plain, as most recently historiography does, because 1) it could have been accessed very easily from the south, 2) it never belonged to Byzantine Empire. In the light of these chroniclers Vlachia must be placed in the Byzantine themata of Bulgaria, which was located in modern Macedonia. This province bordered on Cumania, which can be located close to Macedonian Kumanovo ${ }^{6}$. Involvement of the part of the

${ }^{3}$ Innocentii III Romani Pontificis Regestorum sive Epistolarum liber secundus, Migne. Patrologia Latina (hereinafter: MPL) L, 215, col. 290, e-version: http://www.documentacatholicaomnia.eu/04z/z_11981216_SS_Innocentius_III_Regestorum_Sive_Epistolarum [AD_1203-1208]_MLT.pdf.html; И. Дуйчевъ, Изъ старата българска книжнина, кн. 2, “Хемусь", София 1940, pp. 9-11.

${ }^{4}$ Innocentii II... Epistolarum liber secundus, MPL, 215, col. 281-282 et al.

${ }^{5}$ Robert de Clari, Zdobycie Konstantynopola, transl. and ed. Z. Pentek, Poznań 1997, pp. 61, 95; Geoffrey de Villehardouin [b.c.1160-d.c.1213], Memoirs or Chronicle of The Fourth Crusade and The Conquest of Constantinople, transl. F. T. Marzials, London 1908: http://legacy. fordham.edu/halsall/basis/villehardouin.asp, p. 88 a. next; G. Stabile, Valacchi e Valacchie nella letteratura francese medievale, Roma 2010, pp. 101-124.

${ }^{6}$ There were a few territories referred to as 'Cumania'. In the first place the name was used in relation to the steppes of the Black Sea, also known as the steppes of KipchaksDeszt and Kipchak. There were at least three Cumanias in Hungary: Nagy Kúnsag and Kis Kunsag at the Hungarian Plain and around Braşov. The name of 'Cumania Nigra' also re- 
Vlach nobility in the reconstruction of the Slavic Bulgarian state may indicate its progressive Slavisation. Although the second Bulgarian Empire, like other medieval states, was not a nation-state, there are indications that some Bulgarian tsars led the Slavisation actions among the Vlachs on purpose. Paisij of Hilandar mentions that Kaloyan of Bulgaria forced the Vlachs to use the Slavonic language in church ${ }^{7}$. In reality, the beginning of this process can be associated with the establishment of the first bishopric of Wallachia in the $11^{\text {th }}$ century, subordinated to the archbishopric in Ohrid ${ }^{8}$. This is especially interesting since the tsar led to the union between the Bulgarian Orthodox Church and the Roman Catholic Church, and Vlachs, not only in Bulgaria but throughout the whole Balkans and Central Europe, mostly professed Orthodoxy of the Slavonic Rite. This suggests that they had become the object of Christianization even earlier, together with the Slavs, and were administratively subordinated to the ecclesiastical organization of the states which they inhabited'.

It seems that the Bulgarian state gave the Vlachs good conditions for the development not only within their traditional structures.

Most likely the Wallachian Plain was also a part of Bulgaria for some period of time, though, as mentioned, it should not be identified as the Vlachia province mentioned in the documents by Kaloyan. We do not know exactly when the Vlachs colonized the plain, but certainly in the $13^{\text {th }}$ century the process was completed. In the middle of this century the structures of the Vlach state appeared, namely the principalities of Seneszlau and Litovoi, and later the principality of Wallachia ${ }^{10}$. Although all these countries were then dependent on Hungary, there are indications that the territory of Wallachia was previously associated with Bulgaria. The title the princes of Wallachia is almost an exact copy of the title of the Bulgarian tsars of the second state. The princes of Wallachia, as well as Bulgar-

ferred to the Wallachian Plain. The next (already mentioned Cumania) was situated in the territory of Macedonia.

${ }^{7}$ P. Chilandarski, Stowianobułgarska historia, transl. F. Korwin-Szymanowski, Warszawa 1981, p. 30.

${ }^{8}$ M. Cvetković, Ukljućivanje Slovena i Vlaha u sistem vizantijske provincijske organizacije na jugu Balkana do XI veka. Sličnosti i razlike, "Zbornik Radova Vizantološkog Instituta" 2012,49, p. 34.

${ }^{9}$ In the $14^{\text {th }}$ century there was most likely a Wallachian bishopric in Htetovo $-Ð$. Bubalo, Vlaho episkop ili vlahoepiskop, "Zbornik Radova Vizantološkog Instituta” 2001/2002, 39, pp. 199-220. The analysis of the sources conducted by this scholar clearly presents what great interpretational difficulties this material suggests.

${ }^{10}$ Bela IV in document of 2 June 1247 mentioned principals, Vlachs named Lytuoy and Seneslau - Documente Romaniae Historica, in: Relații între țările române, vol. 1, ed. M. Berza, Bucureşti 1977, pp. 21-28. Maria Holban proposed date 1250 - M. Holban, Din cronica relațiilor româno-ungare în secolele XIII-XIV, Bucureşti 1981, pp. 82-84. 
ian Asen dynasty, took the name "John" while taking the power. Also, Wallachia state system and its entire hierarchy duplicated Bulgarian patterns and in certain territories some similarities in the social structure can also be seen (predominance of large land property). After 1241 these lands were separated from Bulgaria and in the last quarter of the $13^{\text {th }}$ century they fell under the nominal authority of Hungary. The preservation of the Bulgarian administrative system facilitated the formation of the state in this area ${ }^{11}$.

The second state created in the Middle Ages by the Vlachs, Moldavia, largely inhabited by Slavs, was established in the territory periodically belonging to the Halych Ruthenia, for which reason it was called a Rosovlachia which means "The Ruthenian Wallachia". Moldavian state, like the Vlach one, was organized on the model of East and South-Slavic countries, however, it had different social structure than Wallachia. The small and medium land ownership prevailed - it was the inheritance after earlier agricultural land use by Ruthenian peasants ${ }^{12}$.

Both countries created by the Vlachs had a complex ethnic and cultural structure, possibly even Vlachs were not outnumbered. We must therefore consider what decided that they evolved in the direction of the nation-state. First of all, before creating their own countries, they functioned within the Hungarian multi-ethnic state, which in the $12^{\text {th }}$ and $13^{\text {th }}$ centuries willingly managed the various ethnic groups by giving them a far-reaching self-government.

The process of Magyarization of the upper social classes of the Vlach katun reached its apogee only in the $14^{\text {th }}$ century and affected the Vlachs who remained in Hungary, although the Vlach elite that later colonized the Romanian lands, retained its Romance identity. The colonization was clearly associated with a gradual move away from pastoralism to farming and agriculture, as well as a creation of their own centres of power and exchange, namely cities. Only such a comprehensive social development could lead to the creation of statehood.

Nevertheless, also in the Romanian countries long after their creation, there were strong Slavic influences, not only in the sphere of organiza-

${ }^{11}$ The term "Wallachian-Bulgarian state", quite frequently appearing in the Romanian literature lately, suggests that the Vlachs living north off the Danube River had their share in building the monarchy of the first Asens - Ş. Papacostea, Bethween the Crusade and the Mongol Empire, Cluj-Napoca 1998, p. 56; M. Bărbulescu et al., Istoria României, Bucureşti 1998, p. 146. This is a far-reaching over-interpretation; even if it is assumed that the Wallachian Plain was actually a part of the second Bulgarian state, it had to be for a very short period of time and not earlier than during the reign of Ivan Asen.

${ }^{12}$ V. Spinei, Moldova în secolele XI-XIV, Bucureşti 1982, p. 235. 
tion of the state. The language of the church, law and literature was called slavona, which should not be confused with Old Church Slavonic language because it was not the archaic language of the $9^{\text {th }}$ century. Slavona language contains elements of late medieval Slavic languages used on the Russian lands and the Balkans ${ }^{13}$. Wallachian and Moldavian Orthodox Church periodically established closer relations with the autocephalous Archbishopric of Ohrid and the first Vlach Cyrillic printer was brought to Tîrgovişte from Montenegro by completely slavised Vlach Macarius ${ }^{14}$. The numerous political and family relationships with the dynasties of the rulers of the Slavic countries also should be mentioned here, however, we skip these issues as not directly belonging to the subject of the paper.

The development of the settlement of the Vlachs further north to the Ruthenian lands of the Polish Crown, Polish Carpathians and the Subcarpathia led to their fast Slavisation. This process is still almost completely unexplored, the inclusion of the Ruthenian Boykos, Hutsuls and Lemkos to the Vlach ethnic group still remains controversial, but certainly in these ethnic groups Vlach and Slav cultural elements were merged ${ }^{15}$. In contrast, in Podhale and the Beskidy Mountains occurred a fairly rapid process of assimilation of Vlachs with the Polish population. Generally, it can be said that in the lands belonging to the Polish state the process of Polonization of the Vlach population occurred if they had adopted Roman Catholicism and Ruthenisation if they had remained Orthodox ${ }^{16}$.

${ }^{13}$ There are hundreds of sources and reference works on this subject. It is, however, worth mentioning here the studies on language conducted also in Poland by Henryk Misterski (H. Misterski, Recepcja polskich zapożyczeń leksykalnych w dokumentach słowiańsko-mołdawskich, Poznań 1976) and recently by Anna Oczko (A. Oczko, Rumuńska Słowiańszczyzna. Zapożyczenia południowosłowiańskie w języku rumuńskim w XVI i XVII wieku, Kraków 2014).

${ }^{14}$ A. Erich, N. Vârgolici, Istoria cărții româneşti. Controverse privind tipărirea primei cărți în spaţiul românesc Liturghierul (1508), "Studii de Bibliotecoeconomie şi ştiinţa informării" 2009, pp. 140-157, http://www.lisr.ro/13-erichvargolici.pdf.

${ }^{15}$ More recently appears the term of the so-called "Fourth Ruthenia" referring to the Ruthenians or the Carpathian Ruthenians. On the problems associated with their ethnical and cultural categotization see P. Best, S. Stępień (eds.), Does a Fourth Rus' exist? Concerning Cultural Identity in the Carpatian Region, Przemysl-Higganum 2009, passim.

${ }^{16}$ The entire process, particularly with regard to Podhale, is however rather difficult to trace due to the lack of suitable sources. For these relate to permanent colonization, which took place in this territory later than the Polish one, cutting into the already existing Polish settlement. There were very few entirely Wallachian villages in the region of Podhale; the settling of Wallachian families in the villages already inhabited by the Slavic population can be observed more frequently. The settlement of Vlachs was associated with the increase in the level of pastoral culture, in which the Vlachs were champions - S. Górzyński, Z dziejów osadnictwa i pasterstwa Podhala i Tatr w wiekach XII-XVIII, in: Pasterstwo Tatr polskich $i$ Podhala, ed. W. Antoniewicz, vol. 4, Wrocław-Warszawa-Kraków 1962, pp. 18-19, 29-30. 
Also in Hungary the Vlachs remained in more or less close relations with the Slavs. However, they were quite varied various depending on the territory in which Vlachs lived. In the area of Transylvania and Maramures the higher classes of the Vlach society were Magyarizied even in the $14^{\text {th }}$ and $15^{\text {th }}$ century, which was also associated with the adoption of Catholicism, while a number of Vlachs retained their Romanesque identity, language and culture, but still confessed the Orthodoxy of the Slavonic rite ${ }^{17}$. However, one must admit that also in this place the Romanian language was not introduced quickly. The Orthodox Vlach metropolis in Alba Iulia created by Michael the Brave in $1600^{18}$ became in the $17^{\text {th }}$ century the area of conflict between the Slavic-Romanian tradition and Calvino-Hungarian pressures from the Transylvanian dukes. Only archbishop Sava Branković, nota bene of a Serbian descent, introduced in the archdiocese subjected to him the Romanian language as the primary language of the liturgy ${ }^{19}$. Another issue is the adoption by the Romanian Orthodox Church in Transylvania in the late $17^{\text {th }}$ century of the union with the Roman Catholic Church, which, however, did not hinder the maintenance of the Romanian identity. In the other case, the Romanian Orthodox Church in Transylvania was unified with Roman Catholic Church, but this fact was not an obstacle in the preservation of the Romanian identity ${ }^{20}$. The support of Slavic influences, existing from the end of the $14^{\text {th }}$ century, on the Vlachs of Maramures was the Ruthenian bishopric in Munkačevo, subjected to the archbishopric of Sucaeva ${ }^{21}$.

In contrast, on the territory of present Slovakia Vlachs in the Slavic environment fairly quickly succumbed to Slavisation and assimilation. The peak of this process falls on $16^{\text {th }}-17^{\text {th }}$ centuries, in the period of the disintegration of Hungary. In the Habsburg Kingdom of Hungary occurs not only the process of linguistic, but also of religious assimilation by accepting the Roman Catholic and Protestant faith. Part of these Vlachs from Slovakia expanded on Moravia during the Thirty Years War. Perpetrated by the Habsburgs in the mid-1640s pacification of the Wallachian population living in the areas of Moravia resulted in fleeing of their significant

The fact of the late settlement does not exclude, however, the earlier seasonal exploitation of the Polish side of the Carpathians by the Wallachian shepherds, which can be indicated by the already pre-existing local names.

${ }^{17}$ Ş. Meteş, Emigrări româneşti din Transilvania în secolele XIII-XX, Bucureşti 1977, p. 16.

${ }^{18}$ Ş. Andreescu, Mihai Viteazul şi Roma, in: Ş. Andreescu, Restitutio Daciae. Studii cu privire la Mihai Viteazul, vol. 3, Bucureşti 1997, pp. 238-239.

${ }^{19}$ M. Păcurariu, Istoria bisericii ortodoxe române, vol. 2, Bucureşti 1994, p. 86.

${ }^{20}$ Ibidem, p. 92.

${ }^{21}$ Ibidem, pp. 184-195. 
portion to the higher parts of mountains or to the Duchy of Teschen. The later provincial governors of Hukvaldy, Rožnov and Vsetin present themselves already as Slavic. Another thing is that already at the moment of arrival to these areas they had been already to a large extent Ruthenised ${ }^{22}$.

A specific kind of symbiosis of Vlachs and Slavs can also be observed in the western and central parts of the Balkans. In the Middle Ages the Vlachs lived in most of the mountain areas in the Balkans up to the Adriatic coast. In the Middle Ages, the territory between the rivers Lim and Drina in the west, and Raska and Studenica in the east, was called "Old Wallachia" (Stari Vlah), and the Orthodox Church province of the Rasca "eparchy Old Wallachian".

In Serbia of Nemanjić and the states that have later arisen on its ruins, the Vlachs created a fairly closed community because of their special privileged status, in contrast to the rest of Slavic peasant population. Mixed marriages with representatives of other social classes, especially the peasant population, were very difficult here ${ }^{23}$. Despite that, also here the processes of Slavisation and assimilation proceeded very quickly. It was facilitated because of the vanishing of the areas where the Vlach shepherds could wander, because of the distribution of the mountain areas to particular owners. Vlachs defended themselves against dependence for example by buying pastures, which resulted in their definitive transition to semi-sedentary and sedentary life. The Knez and provincial governors (often Vlach ones) became major landowners, entering the group of nobles and even the aristocracy ${ }^{24}$. Among the Slavic Balkan rulers many had Vlach roots - most probably the families Balšić, Hrvatinić - Kosača ${ }^{25}$, and perhaps also Mrnjavcević.

Already the earliest records of the names of the Vlachs as well as the names of localities preserved in the sources of the $13^{\text {th }}$ century show a hybrid combination of Vlach and Slav element. Even then, many Vlach names were Slavic, often with Romanian endings i.e. Dragul, Radul and

${ }^{22}$ V. Chaloupecky, Valaši na Slovensku, v Praze 1947, pp. 64-65; J. Štika, Valaši a Valašsko. O pưvodu Valachü, valašské kolonizaci, vzniku a historii moravského Valašska a také o karpatských salaších, Rožnov pod Radhoštěm 2009, pp. 136-139; Gh. Şişeştean, Românii, care s-au stîns. Valachii din Carpații Nordici şi românii din Ungaria, Cluj-Napoca 2012, pp. 74-76.

${ }^{23}$ N. Trifon, Cincari narod koji nestaje, Beograd 2010, p. 102; А. Матковски, Номадското сточарство во Македонија од ХIV до ХІХ век, Скопје 1996, pp. 26-27.

${ }^{24}$ This process and its variations in different areas of the Balkans was perfectly explained by M. Luković, Transhumantni migrace pastevcu $v$ centrálních a západních oblastech Balkánu, in: Tradiční agrární kultura v kontextu společenského vývoje střední Evropy a Balkánu, Brno 2012, pp. 159-160.

${ }^{25}$ E. Kurtović, Velikij vojvoda bosanski Sandalj Hranić Kosača, Sarajevo 2009, p. 31; А. Ивић, Родословне таблице и грбови српских династија и властеле, Београд 1991, р. 143. 
Bogdan and afterwards even Milutin, Vukašin, Momcil ${ }^{26}$. Starting from the $14^{\text {th }}$ century the term "Vlach" began to lose its ethnical meaning in favour of a societal meaning in the areas of Serbia and Bosnia and Herzegovina. In these areas the Vlachs were strongly mixed with the Slavic population and the name "Vlach" was frequently used interchangeably with the term "Slav"27. The process of gradual Slavisation was, however, interrupted by successive migration waves. Some researchers, i.e. Bogumil Hrabak, recognize a few Wallachian migration waves moving from the south to the north in the areas of Dalmatia and Bosnia and Herzegovina. The oldest migration, in which the Albanian ethnical element was most likely prevalent, underwent Slavisation the fastest. The second wave was of a mixed Romanian and Slavic nature, the process of Slavisation of this group was the slowest. The third wave was to have the most Romanian nature and was to hold on to it for the longes $\mathrm{t}^{28}$. Similar phenomenon was notices by Božidar Šekularac in relation to Montenegro ${ }^{29}$.

The processes of assimilation was easier because the Vlachs were associated with the system of the state through military duty. It seems, however, that paradoxically, Slavisation (in fact Serbisation) of the Vlachs was also encouraged by the period of the Ottoman rule. As Orthodox, Vlachs belonged to the same millet as Serbs, and after the reconstruction of the Serbian Patriarchate of Peć they were subordinated to civil authority of the Serbian patriarch. Thus, Vlachs were integrated with Serbs very quickly, especially that the religious affiliation was the main identifier. The persons who belonged to the Serbian Orthodox Church were called by the name of Serbs, not only in the lands which were traditionally Serbian, also in Bosnia. This process was intensified by the fact that many Vlachs abandoned their activities, especially since enclosed social classes did not exist in the Ottoman state. The majority of Serbs from the Republika Srpska of modern Bosnia is of Vlach origin, as well as the majority of the population from Bosnia and Herzegovina in general. Natural conditions are extremely favourable for the conduct of pastoral activity because of the numerous mountain meadows covered in lush grass (which was rare in the Balkans).

Unfortunately, we do not have the source material directly referring to Vlach colonization of these lands, but many indirect sources explicitly

${ }^{26}$ Š. Kulišić, O etnogenezi crnogoraca, Titograd 1980, pp. 21-24, 30, 88.

${ }^{27}$ Ibidem, p. 25; R. Dodig, Etnička, konfesionalna i regionalna imena i nadimci u Hercegovini XV-XIX st., in: Zbornik Radova s Međunarodnoga znanstvenog skupa održanog u Mostaru 5. i 6. studenoga 2009, ed. I. Lucić, Zagreb 2011, offprint, p. 11.

${ }^{28}$ B. Hrabak, Naseljavanje hercegovačkih i bosanskih vlaha u dalmatinsku Zagoru u XIV, XV I XVI veku, in: I. Mužić, Vlasi u starijoj hrvatskoj historiografiji, Split 2010, p. 199.

${ }^{29}$ B. Šekularac, Tragovi Vlaha u Crnoj Gori, Şebeş 2012, p. 108. 
argue in favour of this problem. For example, in the so-called "Orthodox Bosnian church" we find many elements of traditional mentality and culture of the pastoral people, such as the ideas of community and negation of ownership, as well as little need for institutionalization of power. This is also indicated by the material culture. Not only in Bosnia and Herzegovina, but also of Dalmatia it is possible to find the so-called stećak - gravestones of a specific shape, closely associated with culture of the Vlachs ${ }^{30}$. Unfortunately, we are not able to tell what language was used by the population in Bosnia in the Middle Ages, especially in rural areas; however, state documents were written in Slavonic language with very specific Cyrillic alphabet called bosancica, as well as the inscriptions on stećaks. This may indicate that population was strongly Slavisised already in the Middle Ages. Slavonic language of Bosnian Vlachs survived despite Islamization of the great part of their population in the period of the Ottoman rule, the establishment of regional administrative center of the Ottoman power in the area and permanent stationing of the Ottoman troops. The result is the creation of a specific Slavic-Islamic culture in Bosnia by the population which was ethnically Vlach. One can speak in this area:

1. About Vlachs which evolved into the Serbian nation.

2. About Vlachs which evolved into the Bosnian nation.

Also a third, least numerous group, can be mentioned, namely Roman Catholics who are most often identified with the Croats, although they do not necessarily identify themselves as Croats.

In the area of Croatia and Dalmatia these Vlachs who were present in the early Middle Ages were called Maurovlachs, or Morlachs by the Italians, and they relatively quickly succumbed to Slavisation and catholic faith. They differentiated themselves from the rest of society through their social status, which took on a special meaning in these lands. In the $17^{\text {th }}$ and $18^{\text {th }}$ centuries the term Morlachs determined both Slavisised Vlachs from the area of Dalmatia, as well as Croatian peasants.

Another problem within the issue of the Vlach and Slavic relations is the question of the so-called military borderlands. On the one hand, their origins are related to the special status of the population living in border regions (kraina, krajište) of the Slavic countries ${ }^{31}$, but on the other hand, they were the consequence of military settlement followed by the Hungarian kings. However, there is an important difference between krajište and

${ }^{30}$ I. Mužić, Vlasi i starobalkanska pretkršćanska simbolika jelena na stećcima, in: I. Mužić, Vlasi u starijoj hrvatskoj historiografiji, pp. 215-270.

${ }^{31}$ Д. Мићовић, Крајишничка епика, Београд 1980, pp. 8-9; G. Jawor, Osady prawa wotoskiego i ich mieszkańcy na Rusi Czerwonej w późnym średniowieczu, Lublin 2004, pp. 159-160. 
military borderland: krajište used the natural existing settlements and the military frontier was based on planned settlement executed by the state. The legal basis for the settlement was the Vlach law, which applied not only to the pastoral population living in the mountains, but also to the colonists settled on the frontier in the agricultural areas, exempted from most of the feudal duties in exchange for military service ${ }^{32}$.

The problem of military borderlands and the importance of the Vlachs and the Vlach law and its functioning is a separate and broad topic, which will be presented on another occasion. However, it is important to mention that military border created in the $15^{\text {th }}-19^{\text {th }}$ century by Hungarians, Habsburgs, Venetians and Turks contributed greatly to the strengthening of the Vlach-Slavic ethnic relations. "Vlachs" of military borderlands were of various ethnic backgrounds, many of them were one hundred percent Slavs, but on the other hand, Vlach highlanders were settled there next to the Serbian, Croatian and Bulgarian peasants.

Generally speaking, in the Vlach-Slavic relations in the Middle Ages a certain regularity can be observed. The process of Slavisation of the Vlachs was affected by the following factors:

1. Habitation in the neighbourhood of the Slavs.

2. The preservation of the traditional model of life and economy simultaneously with the absence of their own middle class and their own centers.

3. The involvement of the elites in the state apparatus and the whole Vlach community in the defence system of Slavic countries.

4. Religion identical to those prevailing in the country and organizational affiliation of the church with the church dominant in the country.

Among the factors which counteracted the Slavisation can be considered:

1. Dwelling in an environment other than Slavic, or mixed population.

2. Rapid departure from the traditional way of life and economy, moving entire clans to sedentary life, creation of own craft and commercial centers as well as own middle class.

3. Emergence of the powerful elites seeking their own political emancipation.

4. Religious independence, often despite the Orthodox Slav Rite.

As the most important results of a Vlach-Slavic contacts in the Middle Ages and early modern era should be considered:

${ }^{32}$ Z. Mirdita, Vlasi starobalkanski narod (od povijesne pojave do danas), Zagreb 2009, pp. 139-178. 
1. Slavisation of a considerable part of the Vlachs and their evolution towards Bulgarian, Serbian, Montenegrin, Croatian, Bosnian and Ruthenian nationality.

2. The strong presence of Slavic culture and traditions in medieval Romanian countries - the principalities of Wallachia and Moldavia.

3. Deepening of the ethnic mosaic of the Balkans and the presence of ethnic Vlachs also in the lowlands.

4. Mutual overlapping of cultures and traditions: Vlachs' descent to the lowlands and start the beginning of agricultural activity while the mountains are gradually tamed by the Slavs.

The Vlach-Slavic relations were very important, they contributed in a very significant way to the ethnic and cultural shape of the Balkans, as well as of Central Europe.

\section{BIBLIOGRAPHY}

\section{Primary Sources}

Anna Comnena, The Alexiad, transl. E. A. S. Dawes, Cambridge, Ontario 2000.

Anna Komnena, Aleksjada, transl. O. Jurewicz, vol. 1, Wrocław-Warszawa-Kraków 1967; vol. 2, Wrocław-Warszawa-Kraków 1972.

Documente Romaniae Historica, D: Relații între țările române, vol. 1, ed. M. Berza, Bucureşti 1977.

Geoffrey de Villehardouin [b.c.1160-d.c.1213], Memoirs or Chronicle of The Fourth Crusade and The Conquest of Constantinople, transl. F. T. Marzials, London 1908, e-version: http://legacy. fordham.edu/halsall/basis/villehardouin.asp [accessed on: 16 January 2016].

Georgius Cedrenus, Joannus Skylitzes opere, II, Bonnae 1839.

Innocentii III Romani Pontificis Regestorum sive Epistolarum liber secundus, MPL, 215, col. 290, e-version: http://www.documentacatholicaomnia.eu/04z/z_1198-1216_SS_Innocentius III _Regestorum_Sive_Epistolarum_[AD_12031208]_MLT.pdf.html [accessed on: 16 January 2016].

Robert de Clari, Zdobycie Konstantynopola, transl. and ed. Z. Pentek, Poznań 1997.

\section{Secondary Literature}

Andreescu Ş., Mihai Viteazul şi Roma, in: Ş. Andreescu, Restitutio Daciae. Studii cu privire la Mihai Viteazul, vol. 3, Bucureşti 1997.

Bărbulescu M. et al., Istoria României, Bucureşti 1998.

Best P., Stępień S. (eds.), Does a Fourth Rus' exist? Concerning Cultural Identity in the Carpatian Region, Przemysl-Higganum 2009.

Bubalo Đ., Vlaho episkop ili vlahoepiskop, "Zbornik Radova Vizantološkog Instituta" 2001/2002, 39.

Chaloupecky V., Valaši na Slovensku, v Praze 1947.

Chilandarski P., Stowianobutgarska historia, transl. F. Korwin-Szymanowski, Warszawa 1981. 
Cvetković M., Ukljućivanje Slovena $i$ Vlaha u sistem vizantijske provincijske organizacije na jugu Balkana do XI veka. Sličnosti i razlike, "Zbornik Radova Vizantološkog Instituta" $2012,49$.

Dodig R., Etnička, konfesionalna i regionalna imena i nadimci u Hercegovini XV.-XIX. st., in: Zbornik Radova s Međunarodnoga znanstvenog skupa održanog u Mostaru 5. i 6. studenoga 2009, ed. I. Lucić, Zagreb 2011.

Дуйчевъ И., Изъ старата българска книжнина, кн. 2, София 1940.

Erich A., Vârgolici N., Istoria cărții româneşti. Controverse privind tipărirea primei cărţi în spațiul românesc Liturghierul (1508), "Studii de Bibliotecoeconomie şi ştiinţa informării" 2009, http://www.lisr.ro/13-erichvargolici.pdf.

Górzyński S., Z dziejów osadnictwa i pasterstwa Podhala i Tatr w wiekach XII-XVIII, in: Pasterstwo Tatr polskich i Podhala, ed. W. Antoniewicz, vol. 4, Wrocław-Warszawa-Kraków 1962.

Ивић А., Родословне таблице и грбови српских династија и властеле, Београд 1991.

Holban M., Din cronica relaţiilor româno-ungare în secolele XIII-XIV, Bucureşti 1981.

Hrabak B., Naseljavanje hercegovačkih i bosanskih vlaha u dalmatinsku Zagoru u XIV, XV i XVI veku, in: I. Mužić, Vlasi u starijoj hrvatskoj historiografiji, Split 2010.

Jawor G., Osady prawa wołoskiego i ich mieszkańcy na Rusi Czerwonej w późnym średniowieczu, Lublin 2004.

Kulišić Š, O etnogenezi crnogoraca, Titograd 1980.

Kurtović E., Velikij vojvoda bosanski Sandalj Hranić Kosača, Sarajevo 2009.

Luković M., Transhumantni migrace pastevců v centrálních a západních oblastech Balkánu, in: Tradiční agrární kultura v kontextu společenského vývoje střední Evropy a Balkánu, Brno 2012.

Матковски А., Номадското сточарство во Македонија од XIV до XIX век, Скопје 1996.

Meteş Ş., Emigrări româneşti din Transilvania în secolele XIII-XX, Bucureşti 1977.

Мићовић Д., Крајишничка епика, Београд 1980.

Mirdita Z., Vlasi starobalkanski narod (od povijesne pojave do danas), Zagreb 2009.

Misterski H., Recepcja polskich zapożyczeń leksykalnych w dokumentach stowiańsko-mołdawskich, Poznań 1976.

Mužić I., Vlasi i starobalkanska pretkršćanska simbolika jelena na stećcima, in: I. Mužić, Vlasi u starijoj hrvatskoj historiografiji, Split 2010.

Oczko A., Rumuńska Słowiańszczyzna. Zapożyczenia południowosłowiańskie w języku rumuńskim w XVI i XVII wieku, Kraków 2014.

Păcurariu M., Istoria bisericii ortodoxe române, vol. 2, Bucureşti 1994.

Papacostea Ş., Bethween the Crusade and the Mongol Empire, Cluj-Napoca 1998.

Şişeştean G., Românii, care s-au stîns. Valachii din Carpaţii Nordici şi românii din Ungaria, Cluj-Napoca 2012.

Spinei V., Moldova în secolele XI-XIV, Bucureşti 1982.

Stabile G., Valacchi e Valacchie nella letteratura francese medievale, Roma 2010.

Šekularac B., Tragovi Vlaha u Crnoj Gori, Şebeș 2012.

Štika J., Valaši a Valašsko. O původu Valachů, valašské kolonizaci, vzniku a historii moravského Valašska a také o karpatských salašich, Rožnov pod Radhoštěm 2009.

Trifon N., Cincari narod koji nestaje, Beograd 2010. 


\section{ABSTRACT}

Analysis of the Vlach-Slav relationship in the Middle Ages helped to establish certain regularities in the process of Vlachs' Slavization, or vice versa - in the absence thereof. As the most important results of the Vlach-Slavic contacts in the Middle Ages and early modern era should be considered:

1. Slavisation of a considerable part of the Vlachs and their evolution towards Bulgarian, Serbian, Montenegrin, Croatian, Bosnian and Ruthenian nationality.

2. The strong presence of Slavic culture and traditions in medieval Romanian countries - the principalities of Wallachia and Moldavia.

3. Deepening of the ethnic mosaic of the Balkans and the presence of ethnic Vlachs also in the lowlands.

4. Mutual overlapping of cultures and traditions: Vlachs' descent to the lowlands and the beginning of agricultural activity while the mountains are gradually tamed by the Slavs.

Key words: Vlachs, Slavs, process of Slavization, overlapping of cultures and traditions

\section{ABOUT AUTHOR}

Professor Ilona Czamańska (born 1951) - a professor at Adam Mickiewicz University in Poznan (Faculty of History) and the Head of the Department of Balkan Studies. She specialises in the history of Central and South-Eastern Europe, in particular the history of the Romanian states and Wallachian population through the habitation, interrelations between the South Slavs and other peoples of the Balkans from the Ottoman Empire, Polish-Balkan cultural, genealogical and political associations. She published several books (Mołdawia i Wotoszczyzna wobec Polski, Wegier i Turcji w XIV i XV wieku [Moldavia and Wallachia in relation to the Poland, Hungary and Turkey in the $14^{\text {th }}$ and $15^{\text {th }}$ Centuries], Poznan 1996; Drakula. Wampir, tyran czy bohater [Dracula. Vampire, Bully or a Hero], Poznań 2003, 2 ed. 2013; Wiśniowieccy. Monografia rodu [Wiśniowiecki. Monography of Family], Poznań 2007; Bitwa na Kosowym Polu 1389 [Battle of Kosovo 1389], Poznań 2015, co-author Jan Leśny; source publications (Miron Costin, Latopis Ziemi Mołdawskiej i inne utwory historyczne [Chronicle Earth Moldavian and Other Historical Works], Poznań 1998; Poselstwo Rafata Leszczyńskiego do Turcji w 1700 roku [Legation Rafal Leszczynski to Turkey in 1700], Leszno 1998; Dokumenty klasztoru oo. kamedułów z Pożajścia w Państwowym Archiwum Historycznym w Tbilisi [Documents Monastery Camaldolese Monks from Pažaislis at the State Historical Archive in Tbilisi], Poznań 2012) and dozens of scientific articles. For over twenty years professor Czamańska has been the chief editor of the journal "Balcanica Posnaniensia. Acta et studia", as well as, since 2003, the President of the Commission of the Balkan Studies Polish Academy of Sciences in Poznań. From 2015 she has been leading the research project: Vlachs in the European and Polish cultural space. Migrations - settlement - cultural heritage funded by the National Programme for the Development of Humanities. 